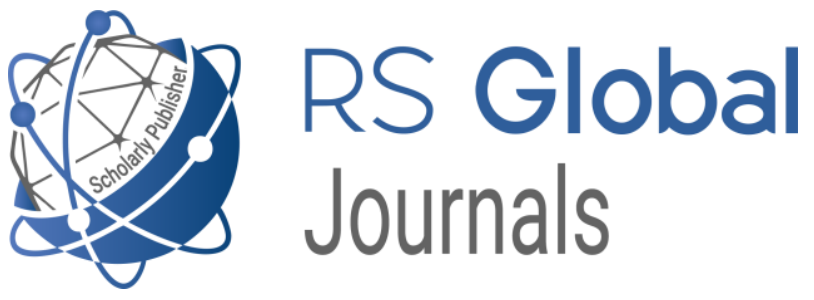

Scholarly Publisher

RS Global Sp. z O.O.

ISNI: 0000000484952390

Dolna 17, Warsaw, Poland 00-773

Tel: +48226022703

Email: editorial_office@rsglobal.pl

JOURNAL International Journal of Innovative Technologies in Social Science

p-ISSN $2544-9338$

e-ISSN

2544-9435

PUBLISHER

RS Global Sp. z O.O., Poland

ARTICLE TITLE

SPEECH CHARACTERISTICS OF JOURNALISTIC TEXTS; JOURNALIST'S SPEECH CULTURE

AUTHOR(S)

M. Avakyan

M. Avakyan. (2021) Speech Characteristics of Journalistic Texts; Journalist's Speech Culture. International Journal of Innovative Technologies in Social Science. 1(29).

doi: 10.31435/rsglobal_ijitss/30032021/7491

DOI

https://doi.org/10.31435/rsglobal_ijitss/30032021/7491

RECEIVED

27 January 2021

ACCEPTED

18 March 2021

PUBLISHED

22 March 2021

\section{(c) (1)}

LICENSE

This work is licensed under a Creative Commons Attribution 4.0 International License.

(C) The author(s) 2021. This publication is an open access article. 


\title{
SPEECH CHARACTERISTICS OF JOURNALISTIC TEXTS; JOURNALIST'S SPEECH CULTURE
}

\author{
M. Avakyan, Russian-Armenian University, Armenia
}

DOI: https://doi.org/10.31435/rsglobal_ijitss/30032021/7491

\section{ARTICLE INFO}

Received 27 January 2021

Accepted 18 March 2021

Published 22 March 2021

\section{KEYWORDS}

speech characteristics, speech culture, mass media, freedom of speech.

\begin{abstract}
The paper examines such notions as speech characteristics of journalistic texts, journalist's speech culture, and its compliance with the language structure of the current language norms. Today a general tendency of deterioration of speech culture in the public may be observed. Such a situation may be explained by "freedom of speech" which today is perceived literally rather than figuratively. However, the language of mass media is a key factor to the formation of not only speech but also mental culture.
\end{abstract}

Citation: M. Avakyan. (2021) Speech Characteristics of Journalistic Texts; Journalist's Speech Culture. International Journal of Innovative Technologies in Social Science. 1(29). doi: 10.31435/rsglobal_ijitss/30032021/7491

Copyright: (C) 2021 M. Avakyan. This is an open-access article distributed under the terms of the Creative Commons Attribution License (CC BY). The use, distribution or reproduction in other forums is permitted, provided the original author(s) or licensor are credited and that the original publication in this journal is cited, in accordance with accepted academic practice. No use, distribution or reproduction is permitted which does not comply with these terms.

The main weapon and tool of a journalist is the word, and, first of all, the culture of speech ${ }^{1}$. The following indicators of speech culture are key for a journalist: correctness of speech -compliance of its language structure with the current language norms; accuracy - the quality of speech associated with the ability to think, with the knowledge of the subject of speech (subject-matter reality) and of the meaning of words; speech logic which characterizes the structure and organization of speech semantics. In addition, as a rule, purity of speech is necessary which implies the absence of elements of language alien to the literary language, rejected by the norms of language, and even morality. Many researchers insist on the expressiveness of speech, embodied in the features of its structure that maintain the attention and interest of the listener or the reader. The richness of speech is often identified with the diversity of speech: it is believed that the less often the same signs and chains of signs are repeated in it, the richer it is, and the concepts of richness and diversity of speech are equated.

"A central criterion of speech culture is its relevance by which is meant a selection andorganization of language tools which make speech meet the goals and conditions of communication. Appropriate speech corresponds to the topic of the message, its logical and emotional content, the audience of listeners or readers, information, educational, aesthetic and other tasks of written or oral speech. Thus, the field of speech culture is that of interaction between language and culture, language and non-linguistic activities, the use of the language taking into account the requirements of the national culture, and the circumstances of communication."2

Nowadays in the age of rapid development of the information society and the so-called informative and communicative revolution not only has the role of information increased, but also the requirements for the modern journalist have changed (it is hard to say whether the change has been towards a higher quality of work and level of culture, or vice versa), which has become a serious issue in many countries, including Armenia. Without making the analysis of the entire complex and diverse

\footnotetext{
${ }^{1}$ Here transmission of information, etc.

${ }^{2}$ Sergeant Yu. Journalist's Speech Culture as a Sign of their Professionalism [in Russian] Retrieved from www.rusnauka.com/26_WP_2012/Philologia/7_116486.doc.htm
} 
process of transformation of the well-known literary language into modern forms of linguistic structures of journalistic materials as the primary goal, one should still mention that significant changes in various media and countries occur in a variety of ways. This is especially true of post-Soviet countries.

In modern society there is a general tendency towards the decline of speech culture. The reasons for this situation include the so-called "freedom of speech" perceived today in the literal, not even in the figurative meaning, verbal negligence, removal of ethical taboos, diverse manifestations of speech aggression, vulgarization and barbarization associated with the expansion of jargons, everyday slangmixing colloquial and literary styles. All these manifestations of low-standard culture or rather lack of culture have become almost regular in the modern media. Scientists directly blame modern media for this "language" scourge claiming that under their influence speech becomes harsh and stereotyped. The mass media, according to researchers, have turned from the accepted standard of correct speech into the replication of mistakes.

Media language researcher O. Sirotininaclaims that it was the media, "with their ill-conceived strategy of democratizing the language of the press... that opened the floodgates to reduce speech at any cost while simultaneously creating a fashion for foreign words and violating Russian communicative norms."

Journalists have begun to use language too freely discarding their influence on people's speech and behavior. They also forgot that professional journalists should have an elite speech culturedetermined by the following features: proficiency in all styles of the literary language, appropriate use of language means in different speech situations, exercise of self-control and compliance with ethical norms of communication and orthological norms. The credibility of the media as a model of the literary language is now a matter of past. "The linguistic norm is our linguistic constitution," notes V. Slavkin. "Fiction, the speech of educated people and the language of the media have always been considered as the source of the norm. Now they "do not function", do not fulfill this role." Numerous facts testify not only to insufficient knowledge of the norms of the literary language, but also to an elementary unwillingness to comply with them. In journalistic texts, violations of linguistic and communicative norms are allowed, which leads to misunderstanding or incorrect perception of the text. In terms of its influencing force, the modern journalistic text becomes more intense and often aggressive. This is primarily due to journalists proffering frequent borrowing in their texts, despite the presence of Russian equivalents; they turn to slang vocabulary, often with aggressive connotations, only because, as they themselves note, it is fashionable now to speak "creative" because this is the linguistic taste of modern society. Yet, it is journalists who primarily create this linguistic fashion. It is the task of the linguist to warn against blindly following the language fashion, and this is where the high level of the national speech culture should be manifested. Actors, directors, poets, linguists and lawyers were invited to discuss the topic "Profanity in Art" within the program "Nothing Personal" (TV Centre, Monday, March 12, 2007, 22.05). The viewers were asked to vote concerning the question "Is swearing in art acceptable?" The results of the voting showed that more than the third of viewers (38\%) - and we are talking about a multimillion spectator audience - agreed that swearing was quite acceptable. It was also surprising that people who should care for the purity of speech spoke out in defense of swearing. The statements of authoritative people voiced in this program, such as "Swearing becomes public and loses its obscenity according to its frequency", "Swearing must be used carefully if we want to maintain its power" or "Swearing is part of the language. And there are people who speak this language. Respect those people!", form the linguistic taste of the audience, influencing the verbal and cogitative activity of members of the culture and, thereby, the national verbal and cogitativeculture.

As the Board Chairman of the Guild of Linguistic Experts, PhD in Philology M. Gorbanevsky notes, "if people use prison language, it means they follow the same value system and the same ideas that come from there." ${ }^{3}$ The professional and social cultures mostly do not overlap in real life. But while we can easily excuse a representative of the working class with "hands of gold" for being rude and using curse words, in the case of a journalist whose speech culture is an indicator of their professional ethics and even of their competency, mistakes in speech or profanities are absolutely inexcusable. In Russia, after a special article was added to the law "On mass media" concerning the

\footnotetext{
${ }^{1}$ Sirotinina $O$. Who does the Fate of the Russian Language Depend on? // Russian Speech. 2007. № 1. [in Russian] ${ }^{2}$ Languageand Culture. Roundtable. // Russian Speech. 2007. № 1 [in Russian].

${ }^{3}$ Samusevich O. Phenomenon of Speech Aggression in Belarus Press // Medialinguistics, Saint-Petersburg 2007, pp. 41-45 [in Russian].
} 
ban on publication of materials which include profanities in 2015, the amount of such content has reduced by almost 5 times (according to the Press Office of the Federal Service for Supervision of Communications, Information Technology and Mass Media of Russian Federation).

The work of a professional journalist is centered around speech, and the professional ethics of a journalist depends on whether they have a good command of the language. Professor N. Ippolitova states: "Culture implies a high degree of mastery; therefore speech culture should be assessed in connection with the mastery of spoken and written language while taking into consideration their specific aspects." However, the modern mass media have become an example of moral decadence and depletion of speech culture, according to M. Gorbanevsky. Now everything is allowed, and the usage of swear words, profanities and colloquial language in public speeches without any consequences is becoming the norm and is exercising influence on the language culture and, accordingly, the life ethics of the younger generation. According to him, this slows down the development of journalism and damages the reputation of this profession in the society. "A journalist must remember that their main tool is their native language. And, it is ultimately journalists who are the ones responsible for the language, at least because they speak and write more than others. And publicly so!" ${ }^{2}$ The problem of the responsibility of journalists before their readers is extremely relevant now. As we have already mentioned, the speech culture and the professional ethics of a journalist imply a skillful command of the language. Even famous journalists sometimes make the mistake using bulky speech constructions that are hard to process. "Now we are switching off the "time machine" and switching on our brains. All the gentlemen who have been mentioned, as well as many others, have become part of history not because they have had conflicts with the tax services, but because they followed the biblical commandment: "The rich are those who give, not those who possess." 3

Alongside with the indefensible choice of colloquial elements, numerous grammatical, lexical, logical, and semantic mistakes also testify to the low-level ethics of commentators. For instance, "now nothing threatens Greis after the yellow T-shirt leader ranking"; "again all fumbled five shots"; "we will follow there the dynamics of lagging..."; "Rösch got closer in terms of his position"; "German female athletes have again occupied the whole winner's podium"; "the ski preparation has improved, but the felicity has come to no good"; "while she is thinking now, the heart is already banging, and not only in her head, but in all other limbs", etc. No comments for the expressions mentioned above.

One of the phenomena of the national culture, without doubts, is language as it reflects the intellectual and creative condition of the nation's culture. Each language reflects the national distinctive way of perception and conceptualization of the realty, as well as the cognitive activity of the members of the culture. The distinction in cultures is reflected in language and human mentality. Speech and thinking are the main characteristics of the logosphere as the verbal and cogitative sphere of the national culture, the development of which affect mass media. It is mass media that affect the verbal and cogitative activity of the society, express the so-called "speech taste" of the era, and form the modern speech ideal.

The state bilingualism of the recent past, with the functional dominance of the Armenian language today, is a feature of the development of the Armenian society (as well as of the mass media). Almost all national mass media clearly reflect the predominant functioning of the native language across the country. However, bilingualism is also present in the modern reality of the Republic of Armenia. Speech incoherence in the country is an obvious danger. First, interference is becoming widespread; its manifestation is one of the reasons for the decline of speech culture in the country. The situation is further complicated by the fact that in recent years independent Armenia has been experiencing a fascination in terms of learning foreign languages, more specifically, English; the penetration of the latter is more intensive and deep than the restoration of the genetic language connection with the Russian language during the late Soviet decades when the Russian language had the status of "state" language. For example, Armenian television mainly uses the Armenian language, which, according to experts, leaves much to be desired.

The result of such a speech situation in the country has been subordinative multilingualism (polylinguism), when the dominant language forms a certain model of verbal and cogitative activity, thereby generating a large number of orthological deviations. Of course, even in the Soviet times Armenia

\footnotetext{
${ }^{1}$ Ippolitova N., Knyazeva O., Savvova M. Russian Language and Culture of Speech, Moscow 2005 [in Russian].

${ }^{2}$ Gorbanevskiy M. On Word Responsibility // Russian Speech 2007. № 1. 3.[in Russian].

${ }^{3}$ Bablumyan S. How to Shake out the Money of Cool Armenians? // "NovoyeVremya", 04.04.2019. [in Russian].
} 
has an interdependent and justified natural bilingualism. It is well-known that phonetic and intonation skills are the most automated ones and thus - the most stable. They can hardly be self-controlled and consciously corrected. Even more so, given that among the republic of Armenia there are still citizens, among them journalists, who have received their education in the USSR. The main disadvantage of the speech of journalists, among whom we often see speakers of mixed bilingualism, is the existence of archaic orphoepic norms in Russian speech and mix of two, non-parallel functioning languages, Armenian and Russian. All of this leads to a situation where the member of the culture group does not have a command of any of the two languages and speaks a mix instead. This cannot help affecting the national cogitative and verbal culture. In this context, we would like to turn to the words of V. Dal, "A language is a century-long toil of a whole generation" which has been nourished throughout dozens of years acquiring forms of the culture of speech. And if not for the influence that it exercised on its users, language would not have been a culture-related phenomenon. Today the preservation of literary language and its norms is "a deed of national importance as literary language is what unites the nation linguistically."

Thus, the mass media language is a most crucial element of the formation of not only speech but also cogitative culture. The speech addressed to an audience of many million people significantly influences people's verbal and cogitative activity and forms their language taste which, given bilingualism leads to a syncretism of cultural and ethnopshycological values of the society and hence to the transformation of the mental categories of the national culture.

\section{REFERENCES}

1. Баблумян C. Как вытряхнуть карманы крутых армян // «Новое время», 04.04.2019г.

2. Ипполитова Н.А., Князева О.Ю., Саввова М.Р., Русский язык и культура речи. М., 2005.

3. ГАРАНТ.РУ: Retrieved from http://www.garant.ru/article/504046/\#ixzz5kDPrrcqU.

4. Горбаневский М.В. Об ответственности за слово // «Русская речь». 2007. № 1. 3.

5. Речевое развитие ребенка в современном образовательном пространстве: методическое пособие для негосударственных ДОО //авт.-сост. Н.В. Багина, А.С. Дёмышева, М.Л. Кусова, Д.О. Иваненко; ФБГОУ ВО «Урал. гос.пед. ун-т. Екатеринбург, 2015. 150 с., С. 109.

6. Самусевич О.М. Речевая культура журналиста как основа профессиональной компетенции (лингвокультурологический аспект) // Культура народов Причерноморья. 2012. № 101.

7. Самусевич O.M., Феномен речевой агрессии в белорусской прессе // Медиалингвистика. С-Пб., 2007. CC. 41-45.

8. Сиротинина О.Б., Сержант Ю.В., Культура речи журналиста как показатель его профессионализма. Retrieved from www.rusnauka.com/26_WP_2012/Philologia/7_116486.doc.htm

9. От кого зависит судьба русского языка? // «Русская речь». 2007. №1.

10. Язык и культура. Круглый стол // «Русская речь». 2007. № 1.

11. Retrieved from https://tass.ru/obschestvo/4487140

\footnotetext{
${ }^{1}$ Citation source: Child's Speech Development in ModernEducational System: Teacher Edition for Non-state Preschool Educational establishments //by N. Bagina, A. Demishyova, M. Kusova, D. Ivanenko, Ural State Pedagogical University, Yekaterinburg 150 pages, P. 109. [in Russian]
} 